\begin{tabular}{l|l|l|}
\cline { 2 - 3 } CRITICAL & $\begin{array}{l}\text { Western Ghats } \\
\text { PARTNERSHIP FUND }\end{array}$ & Special Series \\
\cline { 2 - 3 }
\end{tabular}

\title{
Population dynamics of the Hill Stream loACh ACANTHOCOBitis MOOREH (SYKES, 1839) (CYPRINIFORMES: NEMACHEILIDAE) FROM NORTHERN WESTERN GHATS OF INDIA
}

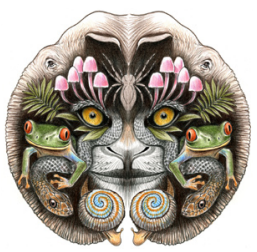

ISSN

Online 0974-7907

Print 0974-7893

OPEN ACCESS

\author{
Sanjay S. Kharat ${ }^{1} \&$ Neelesh Dahanukar ${ }^{2}$ \\ ${ }^{1}$ Department of Zoology, Modern College of Arts, Science and Commerce, Ganeshkhind, Pune, Maharashtra 411007, \\ India \\ ${ }^{2}$ Indian Institute of Science Education and Research, Sai Trinity, Garware Circle, Pune, Maharashtra 411021, India \\ ${ }^{2}$ Zoo Outreach Organization, 96, Kumudam Nagar, Villankurichi Road, Coimbatore, Tamil Nadu 641035, India \\ ${ }^{1}$ kharat.sanjay@gmail.com, ${ }^{2}$ n.dahanukar@iiserpune.ac.in (corresponding author)
}

Abstract: We have studied the sex ratio, length-weight relationship, growth pattern and mortality of a hill stream loach, Acanthocobitis mooreh (Sykes, 1839), from its type locality in northern Western Ghats of India. The sex ratio of $A$. mooreh was unbiased and did not deviate from the expected 1:1 ratio. The power of the lengthweight relationship of $A$. mooreh for both males and females and for the combined population was significantly lesser than the cubic value expected by isometry. Von Bertalanffy Growth Function fitted to the length frequency data suggested that the asymptotic length of the fish is $6.04 \mathrm{~cm}$ while the growth constant is $0.79 \mathrm{y}^{-1}$. Total mortality of the fish is $2.05 y^{-1}$ and the young are more prone to mortality. Both, the high growth rate and high mortality at younger ages indicates that the fish is ' $r$ ' selected.

Keywords: Growth function, length-weight relationship, sex ratio.
Acanthocobitis mooreh was originally described as Cobitis mooreh by Sykes (1839) from Mula-Mutha River of Pune. Because of its remarkable similarity with Acanthocobitis botia, A. mooreh has often been confused as its junior synonym. However, $A$. mooreh can be distinguished from $A$. botia by incomplete lateral line as opposed to complete lateral line in A. botia (Menon, 1987). There is some debate regarding the correct generic status of this species and it has often been put under Noemacheilus (Menon, 1987), Nemacheilus (Talwar \& Jhingran, 1991) and Acanthocobitis (Jayaram, 2010). Currently, the species is recognized as Acanthocobitis mooreh in Eschmeyer (2013).

Acanthocobitis mooreh is endemic to peninsular India (Jayaram 2010) and is common in the upper reaches of the Krishna River system. Some information on the reproductive biology and allometric relationships between different growth and reproduction related

DOI: http://dx.doi.org/10.11609/JoTT.o3301.4562-8 | ZooBank: urn:Isid:zoobank.org:pub:22FE53F0-A8A1-453E-BE19-09EDCBEC0E8E

Editor: Davor Zanella, University of Zagreb, Zagreb, Croatia.

Date of publication: 26 July 2013 (online \& print)

Manuscript details: Ms \# 03301 | Received 11 August 2012 | Final received 25 April 2013 | Finally accepted 29 June 2013

Citation: Kharat, S.S. \& N. Dahanukar (2013). Population dynamics of the Hill Stream Loach Acanthocobitis mooreh (Sykes, 1839) (Cypriniformes: Nemacheilidae) from northern Western Ghats of India. Journal of Threatened Taxa 5(11): 4562-4568; http://dx.doi.org/10.11609/JoTT.03301.4562-8

Copyright: @ Kharat \& Dahanukar 2013. Creative Commons Attribution 3.0 Unported License. JoTT allows unrestricted use of this article in any medium, reproduction and distribution by providing adequate credit to the authors and the source of publication.

Funding: None.

Competing Interest: None.

Acknowledgements: We are thankful to an anonymous reviewer for critical comments on the earlier draft of the manuscript.

The publication of this article is supported by the Critical Ecosystem Partnership Fund (CEPF), a joint initiative of I'Agence Française de Développement, Conservation International, the European Commission, the Global Environment Facility, the Government of Japan, the MacArthur Foundation and the World Bank. 
body parameters of $A$. mooreh is available (Kharat 2001; Kharat et al. 2008). However, not much information is available on the population dynamics of this species. Such information is also relatively rare on loaches, especially from India. Since the information on the population dynamics can aid in understanding the basic ecology of the species and also help in the conservation action (Raghavan et al. 2011; Prasad et al. 2012), in the present study we document the population dynamics, including sex ratio, length-weight relationship and growth and mortality patterns in $A$. mooreh collected from its type locality in Pune, northern Western Ghats of India.

\section{Methods}

Specimens of Acanthocobitis mooreh were collected from Mula-Mutha River, a tributary of Krishna River system, in Pune $\left(18.521^{\circ} \mathrm{N} \& 73.857^{\circ} \mathrm{E}\right.$, elevation $\left.557 \mathrm{~m}\right)$, Maharashtra, India (Image 1) from local fishermen and fish markets. The fish were collected as target fish by the fishermen using dragnet in shallow to waist deep waters with muddy, sandy or pebbly river bed, which is the habitat of the fish. The fish were collected each month for a period of one year and were preserved in $4 \%$ formaldehyde. Number of male and female individuals collected every month are given in Table 1.

The standard length of the fish was measured using dial calipers with a least count of $0.1 \mathrm{~mm}$. The weight of each individual was measured on an electronic weighing balance with a least count of $0.01 \mathrm{~g}$. The sex of the fish was determined by dissecting the fish and identifying the gonads. We used chi-square test to test the null hypothesis that the sex ratio is $1: 1$. Bonferroni correction was used when applying chi-square test for

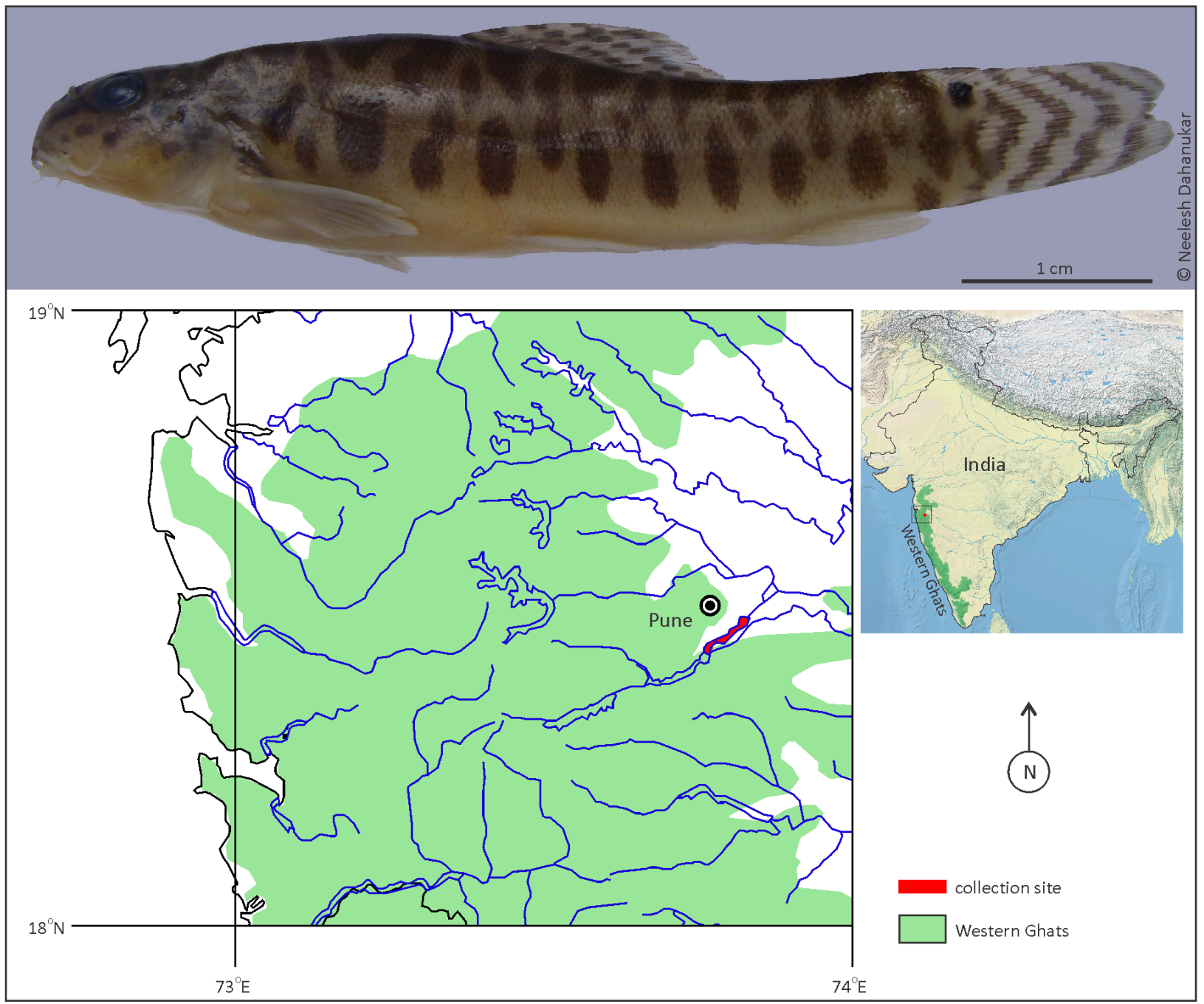

Image 1. Acanthocobitis mooreh lateral view and collection site in the northern Western Ghats. 
multiple comparisons. We plotted length and weight of the fish to determine the power of the length-weight relationship $W=a L^{b}$, where $W$ is the weight, $a$ is the normalization constant, $L$ is the length and $b$ is the scaling power. The null hypothesis that $b=3$ was tested using $\mathrm{t}$ test as described by Zar (1999, pp. 342). To test whether the power $b$, calculated as a slope of the log-log plot for weight and length, was different for males and females, we used $t$ test as described by Zar (1999, pp. 362).

Data were arranged in a length frequency table with $0.25 \mathrm{~cm}$ as the smallest midlength and $0.5 \mathrm{~cm}$ class interval. A contour plot was prepared to understand the distribution of length classes in relation to different months. Growth and mortality parameters, as well as exploitation levels were estimated from the length frequency data using FAO-ICLARM Stock Assessment Tools II (FiSAT II) software (Gayanilo et al. 2005). Asymptotic length $\left(L_{\infty}\right)$ and growth constant $(K)$ of von Bertalanffy Growth Formula (VBGF) were estimated using ELEFAN 1 method (Pauly 1984). Based on $L_{\infty}$ and $K$ values, the growth performance index $\left(\varnothing^{\prime}=2 * \log L_{\infty}+\right.$ $\log K)$ and potential longevity $(3 / K)$ of fish were estimated for different sites (Pauly \& Munro 1984). Total mortality (Z) was estimated from length converted catch curve. Natural mortality $(M)$ was determined using Pauly's $M$ equation, which works well, especially for tropical fish, $\ln (M)=-0.0152-0.279 \ln \left(L_{\alpha}\right)+0.6543 \ln (K)+0.463 \ln (T)$, where, $T$ is the average annual temperature, which is $26^{\circ} \mathrm{C}$. Fishing mortality $(F)$ was calculated as $F=Z-M$ and the current exploitation level $(E)$ was calculated as $E=$ F/Z (Pauly 1984).

\section{Result and Discussion \\ Sex ratio}

We collected 373 individuals of Acanthocobitis mooreh out of which 185 were males and 188 were females. The male to female sex ratio was 1:1.02 (Table 1) and it was not significantly different from $1: 1\left(\chi^{2}=0.02\right.$, $P=0.8766)$. The monthly sex ratio, except for January and October, did not differ significantly from 1:1 (Table 1). Female bias in October was not significantly different from the expected 1:1 ratio when Bonferroni correction was applied and significance was tested at $\mathrm{a}=0.004167$. Bias towards the male individuals in January, however, was significant even after Bonferroni correction and is likely to be a sampling bias rather than a true skew. Thus, we suggest that the sex ratio of Acanthocobitis mooreh does not deviate much from the expected 1:1 ratio.

Even though 1:1 sex ratio has also been observed in some other loaches such as Sabanejewia balcanica (Zanella et al. 2008) and Cobitis simplicispina (Ekmekçi
Table 1. Monthly gender wise frequency of individuals and the chi-square test for expected 1:1 sex ratio. ( $P$ values in bold are significant.)

\begin{tabular}{|l|c|c|c|c|}
\hline Month & Female & Male & Chi-square value & $P$ \\
\hline January & 8 & 29 & 11.92 & 0.0006 \\
\hline February & 19 & 18 & 0.03 & 0.8694 \\
\hline March & 19 & 18 & 0.03 & 0.8694 \\
\hline April & 13 & 9 & 0.73 & 0.3938 \\
\hline May & 23 & 12 & 3.46 & 0.0630 \\
\hline June & 13 & 12 & 0.04 & 0.8415 \\
\hline July & 10 & 10 & 0.00 & 1.0000 \\
\hline August & 9 & 9 & 0.00 & 1.0000 \\
\hline September & 22 & 33 & 2.20 & 0.1380 \\
\hline October & 28 & 12 & 6.40 & $* 0.0114$ \\
\hline November & 11 & 13 & 0.17 & 0.6831 \\
\hline December & 13 & 10 & 0.39 & 0.5316 \\
\hline Total & 188 & 185 & 0.02 & 0.8766 \\
\hline
\end{tabular}

* not significant after Bonferroni correction

\& Akan 2003) in many other loach species such as Cobitis sp. (Kostrzewa et al. 2003), Cobitis calderoni (Valladolid \& Przybylski 2008), Cobitis ohridana (Bohlen et al. 2003), Cobitis narentana (Zanella et al. 2003) and Cobitis tanenia (Marconato \& Rasotto 1989; Boroń et al. 2008) the sex ratio is often biased towards more female dominated populations. In fact, in Cobitis tanenia the male:female sex ratio can sometimes escalate up to 1:22 (Bohlen \& Ritterbusch 2000). Many factors including temperature dependent sex determination, presence of hormone analogue in the environment, sex selected mortality due to predation, intersexual differences in life span or behavior, evolution of hermaphrodism and polyploidy sperm parasitism (Bohlen \& Ritterbusch 2000 and references mentioned within) have been suggested as driving forces for the biased sex ratio. Since Acanthocobitis mooreh showed more or less consistent unbiased sex ratio throughout the year, it is possible that no such external factors affect the $A$. mooreh population in the study area.

\section{Length-weight relationship}

Power $b$ of the length-weight relationship of Acanthocobitis mooreh for the pooled data was 2.8143 ( $S E=0.0539)$ while for males and females it was 2.8135 $(\mathrm{SE}=0.0718)$ and $2.7899(\mathrm{SE}=0.0808)$ respectively (Fig. 1). In all the cases the observed values of power $b$ was significantly different than cubic value expected by isometry (pooled: $t=-3.4418, d f=371, P=0.0006$; male: $t=-2.5970, d f=176, P=0.0102$; female: $t=-2.6021, d f=$ 

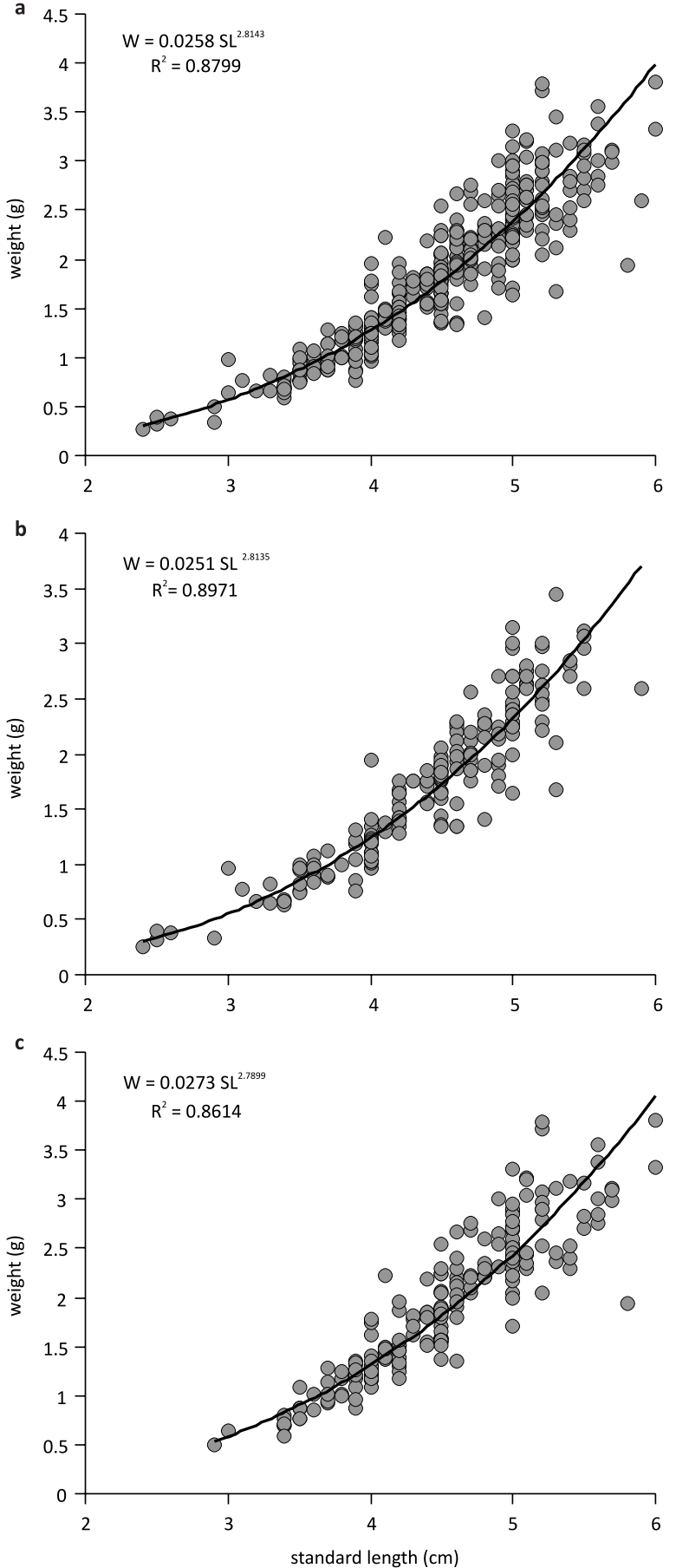

Figure 1. Length-weight relationships for (a) pooled data, (b) males and (c) females. All regressions are significant at $P<0.001$.

$192, P=0.01)$. Thus, the null hypothesis of an isometric relationship was rejected and it can be said that the power of the length-weight relationship in A. mooreh is significantly lesser than an isometric cubic value. Further, the value of $b$ was not significantly different for males and females ( $t=0.2185, d f=368, P=0.8272$ ).
Our value of $b$ for the pooled data is slightly higher than the value determined by Kharat et al. (2008) for Acanthocobitis mooreh. However, in both the cases it could be established that the power $b$ in $A$. mooreh is significantly lesser than 3 . In the case of other loaches it is shown that the value of power $b$ for the pooled data is either close to 3 (Ekmekçi \& Akan 2003; Sánchez-Carmona et al. 2008; Valladolid \& Przybylski 2008) or often more than 3 (Rita Kumari \& Nair 1978; Marconato \& Rasotto 1989, Harka et al. 2002; Dhakal \& Subba 2003; SánchezCarmona et al. 2008). It is suggested that the power $b$ in length-weight relationship of fish differ according to the species, sex, age, season, ontogenic changes, fish feeding, number of specimens examined, differences in the observed length ranges of the specimens caught and additive effect of variation in gonad weight during various stages of sexual maturity (Türkmen et al. 2001; Moutopoulos \& Stergiou 2002; Peck et al. 2005; Froese 2006; Kharat et al. 2008). Less than cubic value of the power in the case of $A$. mooreh could also be an effect of stress response as a part of habitat decline in this area.

\section{Growth}

Distribution of length frequencies across the months are shown in Fig. 2a. Most of the population was observed between 3-6 cm standard length and the length rarely exceeded $6 \mathrm{~cm}$ standard length. Highest frequency of large-sized specimens was observed during February and September (Fig. 2a). This coincides with the spawning period of Acanthocobitis mooreh (Kharat 2001; Kharat et al. 2008). It has been shown that $A$. mooreh spawns twice in a year, once between February/ March and again between August/September (Kharat 2001; Kharat et al. 2008). We fitted the von Bertalanffy Growth Formula to the length frequency data (Fig. 2b) and the $R n$ values depicting goodness of fit for the growth curve was 0.359. Asymptotic length approached about $6 \mathrm{~cm}$ standard length (Table 2), which is consistent with our observations where the large-sized fish only seldom crossed $6 \mathrm{~cm}$ standard length.

In all the loaches studied so far, including Sabanejewia

Table 2. Growth related parameters of Acanthocobitis mooreh.

\begin{tabular}{|l|c|}
\hline Parameter & Value \\
\hline Asymptotic length $\left(\mathrm{L}_{\infty}\right)$ & $6.04 \mathrm{~cm}$ \\
\hline VBGF growth constant $(\mathrm{K})$ & $0.79 \mathrm{y}^{-1}$ \\
\hline Growth performance index $\left(\varnothing^{\prime}\right)$ & 1.46 \\
\hline Potential longevity (3/K) & $3.79 \mathrm{y}$ \\
\hline Power of the length-weight relationship (b) & 2.81 \\
\hline
\end{tabular}



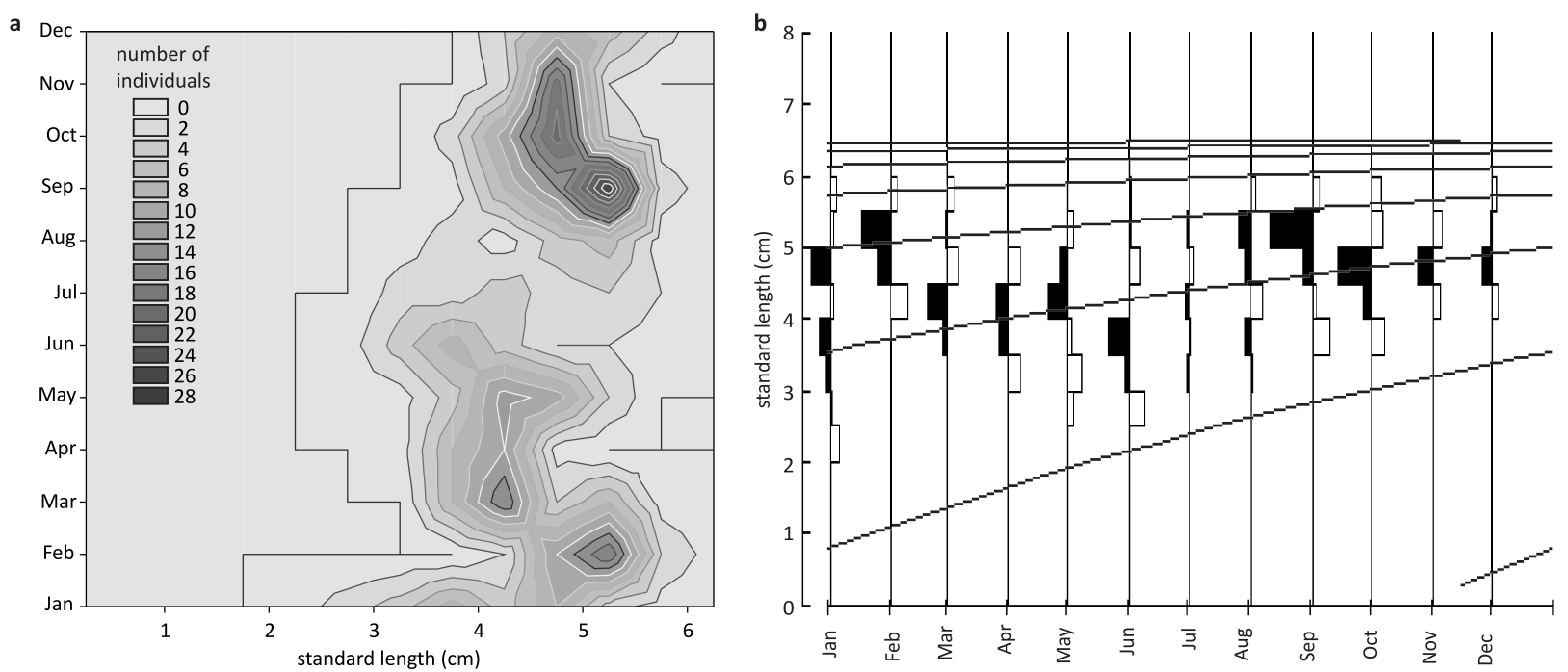

Figure 2. Distribution of standard lengths across months (a) and von Bertalanffy growth function (b).

balcanica (Zanella et al. 2008), S. aurata (Harka et al. 2002), Cobitis sp. (Kostrzewa et al. 2003), C. ohridana (Bohlen et al. 2003), C. simplicispina (Ekmekçi \& Akan 2003) and Barbatula zetensis (Bohlen et al. 2003), the growth constant $(\mathrm{K})$ is much lower than that for $A$. mooreh. Coupled with the fact that $A$. mooreh also has a much smaller asymptotic length, it can be said that $A$. mooreh grows very rapidly towards maturity.

\section{Mortality}

We used length converted catch curve (Fig. 3a) to determine various mortality related parameters (Table 3) and plotting of length structured virtual population analysis (Fig. 3b). A. mooreh has a very high natural mortality rate of $2.05 \mathrm{y}^{-1}$ and with the fishing mortality of $0.26 \mathrm{y}^{-1}$ the total mortality (Z) of $A$. mooreh is $2.31 \mathrm{y}^{-1}$ (Table 2). This is much higher than that reported for another loach Sabanejewia aurata (Harka et al. 2002). For A. mooreh, natural mortality was higher during the early age groups and it decreased with the size of the fish while the fishing mortality increased with the size (Fig. 3b). A. mooreh is often caught by tribal people in this area and are sold in local fish markets. The fishing mortality of the

Table 3. Mortality related parameters for the population of Acanthocobitis mooreh.

\begin{tabular}{|l|c|}
\hline Parameter & Value \\
\hline Length at first capture (LC) & $4.51 \mathrm{~cm}$ \\
\hline Natural mortality (M) & $2.05 \mathrm{y}^{-1}$ \\
\hline Fishing mortality (F) & $0.26 \mathrm{y}^{-1}$ \\
\hline Total mortality (Z) & $2.31 \mathrm{y}^{-1}$ \\
\hline Exploitation rate (E) & 0.13 \\
\hline
\end{tabular}
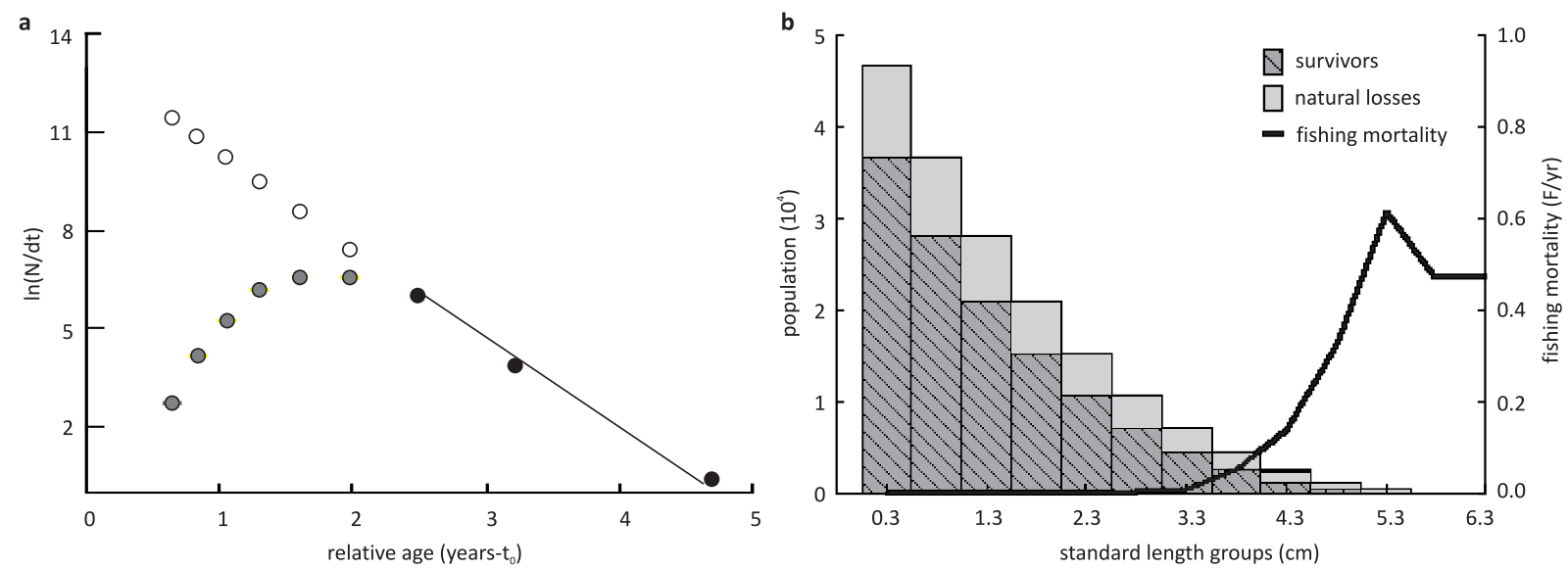

Figure 3. Mortality parameters for the population. (a) Length converted catch curve and (b) length structured virtual population analysis. 
fish is very low at $0.26 y^{-1}$ with the exploitation rate of 0.13 indicating that fishing is not a threat to the populations of $A$. mooreh. The fact that $\mathrm{A}$. mooreh has a high growth rate (Table 2 ) and high mortality in the young age (Fig. $3 b)$, indicates that the species is ' $r$ ' selected.

\section{Conclusion}

Even though Acanthocobitis mooreh has been assessed as Least Concern species in IUCN Redlist, owing to its wide distribution and absence of any recognizable wide spread threat to the species, it has been pointed out that some of the populations of the species are facing threats because of pollution of water bodies and loss of habitat (Raghavan \& Ali 2011). Especially in the current study area increase in the extent of urbanization has severely threatened the population of the species. The population of the species, which was once considered as abundant in Pune urban area (Kharat et al. 2001), has declined drastically in the recent past and has become fragmented because of habitat modifications, recreational activities and levels of pollution in different stretches of the river. Such threats are known for other populations of $A$. mooreh as well (Dahanukar et al. 2012; Kharat et al. 2012). Since, any conservation action plan targeted towards the species could be a futile exercise in the absence of knowledge about the ecology of the species, we believe that the current study will contribute significantly to our knowledge about the ecology of $A$. mooreh and may also provide insights about the ecology of loaches of the Western Ghats in general.

\section{REFERENCES}

Bohlen, J., V. Šlechtová, R. Šanda, L. Kalous, J. Freyhof, J. Vukic \& D. Mrdak (2003). Cobitis ohridana and Barbatula zetensis in the River Morača Basin, Montenegro: distribution, habitat, population structure and conservation needs. Folia Biologica (Kraków) 51: 147-153.

Bohlen, J. \& D. Ritterbusch (2000). Which factors affect sex ratio of spined loach (genus Cobitis) in Lake Müggelsee? Environmental Biology of Fishes 59: 347-352; http://dx.doi.org/10.1023/A:1007695703991

Boroń, A., I. Jeleń, D. Juchno, M. Przybylski \& E. Borzuchowska (2008). Age and growth of the karyologically identified spined loach Cobitis taenia (Teleostei, Cobitidae) from a diploid population. Folia Zoologica 57(1-2): 155-161.

Dahanukar, N., M. Paingankar, R.N. Raut \& S.S. Kharat (2012). Fish fauna of Indrayani River, northern Western Ghats, India. Journal of Threatened Taxa 4(1): 2310-2317; http://dx.doi.org/10.11609/ JoTT.02771.2310-7

Dhakal, A. \& B.R. Subba (2003). Length-weight relationship of Lepidocephalichthys guntea of Pathri Khola, Morang District. Our Nature 1: 53-57.

Ekmekçi, F.G. \& F.E. Akan (2003). Preliminary data on growth and reproduction of Cobitis simplicispina from Turkey. Folia Biologica (Kraków) 51: 183-186.

Eschmeyer, W.N. (2013). Catalog of Fishes electronic version. http:// research.calacademy.org/ichthyology/catalog/fishcatmain.asp. Online version dated 25 March 2013. Accessed on 12 April 2013.

Froese, R. (2006). Cube law, condition factor and weight-length relationships: history, meta-analysis and recommendations. Journal of Applied Ichthyology 22: 241-253; http://dx.doi.org/10.1111/ j.1439-0426.2006.00805.x

Gayanilo, F.C. Jr., P. Sparre \& D. Pauly (2005). FAO-ICLARM Stock Assessment Tools II (FiSAT II). User's Guide. FAO Computerized Information Series (Fisheries) No. 8. FAO, Rome, 168pp.

Harka, Á., K. Györe \& P. Lengyel (2002). Growth of the golden spined loach Sabanejewia aurata (Filippi, 1865) in River Tisza (Eastern Hungary). Tiscia 33: 45-49.

Jayaram, K.C. (2010). The Freshwater Fishes of the Indian Region. Second Edition. Narendra Publishing House, Delhi, 616pp.

Kharat, S.S. (2001). Study of reproductive biology of Nemacheilus moreh (Sykes). PhD Thesis. Submitted to Dr. Babasaheb Ambedkar Marathwada University, Aurangabad, India.

Kharat, S.S., N. Dahanukar \& R. Raut (2001). Decline of freshwater fish of Pune urban area. Journal of Ecological Society 13/14: 46-51.

Kharat, S.S., Y.K. Khillare \& N. Dahanukar (2008). Allometric scaling in growth and reproduction of a freshwater loach Nemacheilus mooreh (Sykes, 1839). Electronic Journal of Ichthyology 4(1): 8-17.

Kharat S.S., M. Paingankar \& N. Dahanukar (2012). Freshwater fish fauna of Krishna River at Wai, northern Western Ghats, India. Journal of Threatened Taxa 4(6): 2644-2652; http://dx.doi.org/10.11609/ JoTT.02796.2644-52

Kostrzewa, J., M. Przybylski, L. Marsza \& M. Valladolid (2003). Growth and reproductive biology of loaches Cobitis sp. in Lake Lucieñ, Poland. Folia Biology (Kraków) 51(Suppl.): 179-182.

Marconato, A. \& M.B. Rasotto (1989). The biology of a population of spined loach, Cobitis taenia L. Italian Journal of Zoology 56(1): 73-80; http://dx.doi.org/10.1080/11250008909355624

Menon, A.G.K. (1987). The Fauna of India and Adjacent Countries, Pisces, Vol 4, Teleostei-Cobitoidea, Part 1, Homalopteridae. Zoological Survey of India, Kolkata, 259pp.

Moutopoulos, D.K. \& K.I. Stergiou (2002). Length-weight and length-length relationships of fish species from the Aegean Sea (Greece). Journal of Applied Ichthyology 18: 200-203; http://dx.doi. org/10.1046/j.1439-0426.2002.00281.x

Pauly, D. (1984). Fish population dynamics in tropical waters: a manual for use with programmable calculators. ICLARM Studies and Reviews 8: $1-325$

Pauly, D. \& J.L. Munro (1984). Once more on the comparison of growth in fish and invertebrate. ICLARM Fishbyte 2(1): 21.

Peck, M.A., C. Clemmesen \& J.P. Herrmann (2005). Ontogenic changes in the allometric scaling of the mass and length relationship in Sprattus sprattus. Journal of Fish Biology 66: 882-887; http://dx.doi. org/10.1111/j.0022-1112.2005.00651.x

Prasad, G., A. Ali, M. Harikrishnan \& R. Raghavan (2012). Population dynamics of an endemic and threatened Yellow Catfish Horabagrus brachysoma (Günther) from Periyar River, southern Western Ghats, India. Journal of Threatened Taxa 4(2): 2333-2342; http://dx.doi. org/10.11609/JoTT.02590.2333-42

Rita Kumari, S.D. \& N. B. Nair (1978). Length-weight relationship of the loaches Noemacheilus triangularis Day and Lepidocephalus thermalis (Cuv. \& Val.). Matsya 4: 52-58.

Raghavan, R. \& A. Ali (2011). Nemacheilus mooreh. In: IUCN 2012. IUCN Red List of Threatened Species. Version 2012.2. <www. iucnredlist.org>. Downloaded on 19 April 2013.

Raghavan, R., A. Ali, N. Dahanukar \& A. Rosser (2011). Is the fishery for the Deccan Mahseer, Tor khudree (Sykes, 1839) in the Western Ghats Hotspot sustainable? A participatory approach to stock assessment. Fisheries Research 110: 29-38; http://dx.doi. org/10.1016/j.fishres.2011.03.008

Sánchez-Carmona, R., L. Encina, A. Rodríguez-Ruíz \& V. RodriguezSánchez (2008). Age, growth and diet of the Iberian loach, Cobitis paludica in two different environments. Folia Zoologica 57(4): 420434.

Sykes, W.H. (1839). On the fishes of the Deccan. Proceedings of the 
General Meetings for Scientific Business of the Zoological Society of London 6: 157-165.

Talwar, P.K. \& A.G. Jhingran (1991). Inland Fishes of India and Adjacent Countries. Oxford-IBH Publishing Co. Pvt. Ltd., New Delhi, 1158pp.

Türkmen, M., O. Erdoan, H. Hallolu \& A. Yildirim (2001). Age, growth and reproduction of Acanthalburnus microlepis, Filippi 1863 from the Yagan Region of the Aras River, Turkey. Turkish Journal of Zoology 25: 127-133.

Valladolid, M. \& M. Przybylski (2008). Life history traits of the endangered Iberian loach Cobitis calderoni in the River Lozoya, Central Spain. Folia Zoologica 57(1-2): 147-154.

Zanella, D., M. Markovčič, D. Schneider, P. Mustafič, M. Čaleta \& I. Radič (2003). Growth of Cobitis narentana Karaman, 1928 in the Neretva River, Croatia. Folia Biologica (Kraków) 51: 155-157.

Zanella, D., M. Mrakovčić, P. Mustafić, M. Ćaleta, I. Buj, Z. Marčić, S. Zrnčić \& J. Razlog-Grlica (2008). Age and growth of Sabanejewia balcanica in the Rijeka River, central Croatia. Folia Zoologica 57(12): 162-167.

Zar, J.H. (1999). Biostatistical Analysis - Fourth Edition. Pearson Education, India, 662pp. 